УДК 342.95

DOI https:// doi.org/10.32837/yuv.v0i1.2105

\author{
Д. Малетов, \\ аспірант, \\ фахівець кафедри адміністративного, господарського права \\ та фінансово-економічної безпеки \\ Навчально-наукового інституту права \\ Сумського державного університету
}

\title{
АДМІНІСТРАТИВНО-ПРАВОВІ ЗАСАДИ ОРГАНІЗАЦІЇ ТА РЕФОРМУВАННЯ ІНДОНЕЗІЙСЬКОГО АНТИКОРУПЦІЙОНОГО СУДУ ТІПІКОР
}

Вступ. Індонезія має довгу історію боротьби з корупцією. Індонезійський антикорупційний суд Тіпікор був створений в 2002 році разом з прийняттям відповідного закону. Антикорупційний закон визнав корупцію надзвичайним злочином й запровадив засади державної політики викоренення цього негативного явища. Суд знаходився в столиці й діяв як суд першої та апеляційної інстанцій. Антикорупційному суду Тіпікор були підсудні справи спеціалізованого органу - Kомісії по викорененню корупції. Запровадження суду було вдалим кроком - кількість обвинувальних вироків зросла й довіра до судової гілки влади почала відновлюватись. Поряд з новоствореною антикорупційною системою паралельно існували звичайні, нереформовані суди які розглядали більшість корупційних злочинів за обвинуваченням прокуратури. Їхні показники роботи мали значно менший результат ефективності ніж у спеціалізованих інституцій. У 2009 році існування дуалістичної системи судочинства було визнано неконституційним. Після цього була розпочата реформа з метою поширення позитивного досвіду суду Тіпікор на інші окружні суди.

Аналіз останніх досліджень i публікацій. Питання запровадження та функціонування антико- рупційного суду в Індонезії вивчалося у роботах у таких іноземних науковців, як Сімон Б., Шутте С., Новера А., Пратама К., Віряні Ф., Сетійоно Дж. та інших.

Метою цією статті є дослідження становлення та реформування адміністративно-правової бази антикорупційного судоустрою в Індонезіі.

Досягнення поставленої мети можливе через такі завдання: проведення аналізу етапів становлення антикорупційного законодавства в Індонезіі, дослідження запровадження суду Тіпікор та його реформування, оцінка потенційних напрямів вдосконалення роботи суду.

Виклад основного матеріалу. Індонезія, із часу набуття незалежності, має довгу історію формування та впровадження антикорупційних механізмів. Ії досвід є доволі успішним, про що свідчить відповідний Індекс сприяння корупції (рисунок 1). Відповідно нього Індонезія, з 2003 року майже незмінно покращує свої позиції в рейтингу країн, які успішно провадять боротьбу з корупційними явищами [1].

Але відповідні показники сприйняття корупції у країн відповідного регіону можуть бути й кращі. Наприклад, порівнюючи антикорупційний досвід Малайзії та Індонезії, можемо спостерігати, що в останньої 


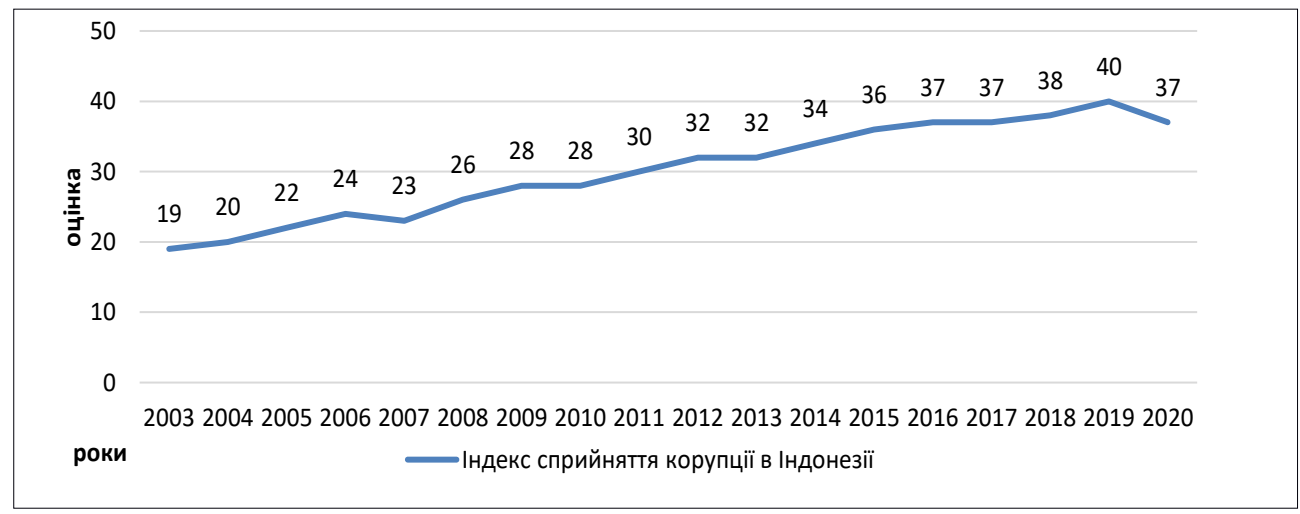

Рис. 1. Індекс сприяння корупції в Індонезії (2003-2020 роки)

Джерело: розроблено автором, на основі Transparency International CORRUPTION PERCEPTIONS INDEX: INDONESIA.

URL: https: / / www.transparency.org/en/cpi/2020/index/idn

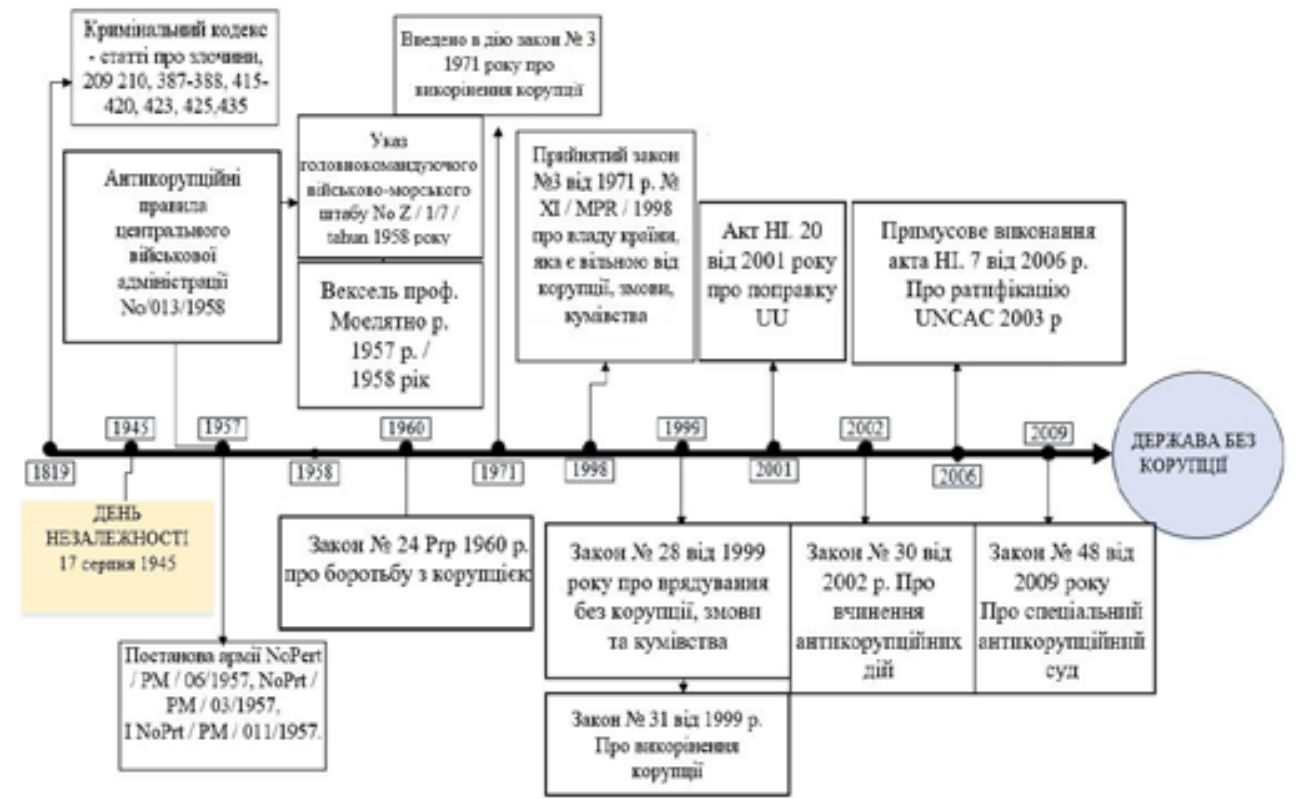

Рис. 2. Розвиток антикорупційного законодавства Індонезії

Джерело: Najih, M., \& Wiryani, F. (2020). Learning the Social Impact of Corruption: A Study of Legal Policy and Corruption Prevention in Indonesia and Malaysia. Journal of Social Studies Education Research, 11(4), 175-189.

законодавча база щодо запобігання та усунення корупції більше зосереджуються на покаранні [2].

Такий висновок можливо зробити, досліджуючи індонезійське законодав- ство, яке детально окреслює широкий спектр корупційних правопорушень (рисунок 2).

Антикорупційна нормативно-правова база Республіки Індонезія у 
процесі свого становлення деталізувалась та поступово утворила систему відповідних органів. Вона передбачає створення правоохоронного органу 3 розслідування корупційних справ та функціонування спеціалізованих судів.

У індонезійській судовій системі злочини, пов'язані з корупцією, розглядає спеціалізований антикорупційний суд - Pengadilan Tindak Pidana Korupsi , більш відомий як Пінгаділан Тіпікор, або спрощено - суд Тіпікор. Він був створений з прийняттям окремого закону у 2002 році та розпочав свою діяльність у 2004 році.

До 2010 року антикорупційний суд першої інстанції знаходився на території Центрального районного суду м. Джакарта - столиці Індонезіі. Апеляції подавались до палат Тіпікор створених у Вищому суді Джакарти. Остаточна касаційна інстанція знаходилася в Верховному суді. У кожній інстанції справу розглядали не менше п'яти осіб: двоє суддів за професією та троє спеціально залучених судді ad hoc. Судді ad hoc відбираються Верховним судом, з числа громадян, які не працюють у судовій системі та мають спеціальні знання, строком на п'ять років.

Законом 2002 року також був утворений спеціалізований антикорупційний правоохоронний орган - Комісія 3 викоренення корупції в Індонезіі (Komisi Pemberantasan Korupsi далі Комісія). Суду Тіпікор були підслідні справи, досудове розслідування яких здійснювала Комісія.

Разом із тим місцеві суди загальної юрисдикції продовжували здійснювати розгляд правопорушень, пов'язаних 3 корупцією. Досудове слідство у таких справах здійснювала прокуратура. Одночасно існували дві паралельні системи розгляду кримінальної справи, пов'язаної з корупцією. Різні процесуальні процедури та значні відмінності у показниках обвинувальних та виправдувальних вироках призвели до звинувачення в правовому дуалізмі.
Тож, з одного боку, Індонезія мала невелику, але дієву спеціальну судову систему, яка показувала високий результат своєї діяльності і користувалася довірою суспільства. 3 іншоїсудову систему судів загальної юрисдикції, котра розглядала більшість справ, мала сумнівну ефективність та не знаходила підтримки та довіри громадськості.

У 2006 році Конституційний Суд Індонезії визнав одночасно існуючу дворівневу система антикорупційного судоустрою такою, що не відповідає Конституції. У свою чергу, законодавча влада прийняла в 2009 році новий закон, який розширив юрисдикцію судів Типікор на розгляд всіх кримінальних справ, пов'язаних 3 корупцією, а також злочинів щодо відмиванням грошей, незалежно від підслідності справи. Відповідно до ухваленого закону протягом двох років створювалися регіональні антикорупційні суди у всіх 34 провінціях Індонезії.

Також новий закон 2009 року не включав положення щодо фіксованого співвідношення двох професійних суддів і трьох суддів ad hос. Відповідно до нової редакції кількість спеціально залучених суддів ad hoc визначається головою регіонального антикорупційного суду, де розглядається справа. Але для запобігання випадків з однаковою кількістю протилежних голосів кількість суддів повинна бути непарною. Надання дискреційних повноважень головам судів із визначення кількості залучених суддів із громадськості було зумовлено проблематичністю пошуку осіб, котрі відповідали б критеріям суддів ad hoc у деяких регіонах. Також важливими змінами $€$ зміни 3 розширення підсудності антикорупційних судів. Суд Тіпікор у Джакарті розглядав справи підслідні спеціалізованому правоохоронному органу - Комісії з ліквідації корупції (Komisi Pemberantasan Korupsi далі Комісіі). Після реформи 2009 року, всі 34 суди індонезійських провінцій 
почали розглядати справи як розслідувані Комісією так і прокуратурою.

Попередній закон 2002 року встановлював дуже стислі строки для судового розгляду провадження: для першої інстанції (суду Tipikor) 90 днів. $\mathrm{Ha}$ розгляд апеляції відводилось 60 днів, й для касаційної касаційної скарги до Верховного суду - 90 днів відповідно. Такі суворі терміни були встановлені, щоб унеможливити затягування розгляду корупційних справ у судах. Порівнюючи з новим законом 2009 року, можемо констатувати, що максимально допустимі терміни судового розгляду дещо збільшилися. Так, за новими правилами першій інстанції відводилось 120 днів, для апеляції 60-денний термін й для касаційного розгляду - 120 днів [3]. Вважаємо, збільшення термінів судового розгляду доцільним, адже занадто стислі строки, які були визначені в попередньому законі, можуть негативно впливати на якість здійснення правосуддя й порушувати права людини.

Створені у зв'язку із прийняттям нового закону про антикорупційний суд, регіональні суди Індонезії також мали певну проблематику від самого початку створення. В першу чергу, це була проблема кадрового потенціалу. Як було зазначено, реформа передбачала створення 34 регіональних судів першої інстанції замість одного антикорупційного суду, котрий працював у столиці. Звісно, це покликало за собою потребу в додатковому розширені штату та пошуку кваліфікованих й доброчесних суддів. Однак це не означає що регіональні антикорупційні суди були непрофесійними та взагалі менш ефективними за місцеві суди першої інстанції. Низький рівень довіри населення та питання до ефективності в контексті розгляду корупційних справ судами загальної юрисдикції й було передумовою для створення судів Тіпікор.

У своєму дослідженні Сімон Б. доходить висновку, що результати діяльності новостворених антикоруп- ційних судів не повинні оцінюватися за результатами роботи суду Тіпікор в Джакарті. Навіть якщо брати за оцінку успішності роботи суду показник кількості виправдувальних вироків, наявні дані вказують на те, що кількість виправдувальних вироків регіональних судів Тіпікору нижчі, ніж у судів, яких вони замінили після реформи. Дослідник вважає, що із плином часу судді регіональних антикорупційних судів Тіпікор спеціалізуються на справах про корупційні правопорушення та напрацюють досвід, й рівень обгрунтованості судових рішень значно покращиться.

Після прояву зазначених проблем та звинувачення деяких суддів у корупції були пропозиції скасувати реформу та утворені внаслідок неї регіональні суди. Але ми погоджуємося $з$ пропозицією науковця зосередитись на вирішенні конкретних проблем замість повного скасування новоутворених інституцій. Також ми поділяємо його думку, що повна відсутність виправдувальних вироків не $€$ показником надійності й ефективності судової установи. Це, навпаки, може свідчати про репресивність судової інстанції та однобічність процесу розгляду справи. Під час здійснення антикорупційного правосуддя перш за все повинні бути дотримані належні юридичні процедури та принцип верховенства права. Антикорупційна судова система повинна бути справедливою і неупередженою, щоб у довгостроковій перспективі залишатися легітимною. Задля подолання корупції по всій країні потрібно підіймати загальні стандарти якості правосуддя до одного рівня й підвищувати професіоналізм вже працюючих установ [4].

Іншою перспективою покращення роботи антикорупційних судів Тіпікор є належна організація процесу 3 використанням сучасних технологій. Географічними особливостями Республіки Індонезія є те, що територіально країна розташовується на 
сукупності вулканічних островів і по суті являє собою архіпелаг. Навіть після проведення реформи 2009 року й утворення 34 регіональних антикорупційних судів очна участь прокурорів у засіданні, залучення свідків та інших учасників засідання не завжди є можливим та доцільним.

Було проведено дослідження для оптимізації роботи моделі суду Тіпікор 3 урахуванням територіальних особливостей архіпелагу. Відповідно до частини першої статті 35 до пункту Закону № 462009 року регіональні суди Тіпікор розташовуються в кожному головному місті регіону. Юрисдикція такого суду охоплює відповідну провінцію, де він територіально розташований.

Під час дослідження було встановлення, що витрати, понесені для забезпечення належної процесуальної роботи досудового та судового слідства і однієї справи в суді Тіпікор, у деяких віддалених регіонах, сильно різняться, (від 127,534,000 до376556000 рупій). Різниця у витратах зумовлена відстанню від міста то розташування судів. Чим більша відстань від міста, тим більші витрати на організацію досудового та судових процесів. Крім того, це впливає на процесуальну оперативність та тривалість судового розгляду взагалі. Виходячи з вищезазначеного, значною перспективо вдосконалення індонезійських антикорупційних судів є створення моделі регіонального суду Тіпікор, який буде основуватись на інформаційних технологіях та електронному діловодстві. Це допоможе заощадити відносно дорогі витрати та скоротити час розгляду справ [5].

Індонезійські науковці поділяють думку, що ідея застосування технологічного прогресу взагалі та електронного суду зокрема у сфері діяльності антикорупційних судів Тіпікор має філософську та юридичну основу й направлена на посилення зусиль 3 викорінення корупції у країні. Філософська ідея застосування системи електронного суду в процесі здійснення антико- рупційного правосуддя відповідає цінностям, які відображають основні правила та ідеали Конституції Індонезіі. Тоді як заснована на юридичному підгрунті парадигма застосування системи електронного суду в антикорупційних судах відповідає чинному Закону № 48 від 2009 року в частині, що судова влада, при здійсненні правосуддя, повинна робити його більш швидким, простим i доступним для громадян. По-друге, запуск електронного судочинства забезпечить більш оперативний розгляд справ та покращить судову взаємодію в середині системи. Також застосування системи електронного суду в регіональних антикорупційних судах полегшить умови здійснення громадського контролю за станом розгляду суспільно-резонансних корупційних справ, одночасно підвищить прозорість суду та розуміння громадськості юридичних аспектів розгляду судових справ антикорупційного спрямування [6].

Висновки. Отже, виходячи з вищенаведеного, можливо зробити такі висновки:

1. Республіка Індонезія має свою історію антикорупційної боротьби. Завдяки імплементації антикорупційного суду в судову систему Індонезії країна покращила свої позиції в міжнародному рейтингу сприйняття корупції.

2. Створений у 2002 році суд із протидії корупції Тіпікор у столиці мав відчутний успіх й користувався довірою населення. Завдяки його роботі, рівень корупції знизився, та розгляд справ здійснювався ефективно та 3 низьким рівнем виправдувальних вироків. У 2009 році фактично наявна дуальна система судоустрою була визнана такою, що суперечить конституціі. Після цього почалася реформа, яка передбачала створення 34 антикорупційних регіональних судів. I хоча під час реформи постали деякі питання, такі як нестача кваліфікованих кадрів, здебільшого зазначені зміни можливо вважати вдалими. Вважаємо, що при реформах такого типу ключовим $€$ збереження 
позитивного досвіду оригінального суду та його поширення на новостворену систему установ судової гілки влади. Індонезійський досвід реформування антикорупційних судових інституцій, показав, що запровадження регіональних судів Тіпікор допомогли розширити коло доступності антикорупційного судочинства та розвантажили місцеві суди загальної юрисдикції, що підвищило загальнонаціональний рівень протидії корупції.

3. Завдяки географічним особливостям антикорупційна система судоустрою Індонезії особливо гостро відчуває потребу в оптимізації й повному переході на електронне судочинство. Це є істотною перспективою для покращення судів Тіпікор. Із розвитком технологій та впровадження ix у судову систему доступність судочинства буде зростати, а видатки на його здійснення зменшуватись, що $є$ особливо актуальним для найвіддаленіших регіонах країни.

У статті здійснюеться дослідження процесу історичного формування антикорупиійного законодавства Індонезіі. Особливу увагу автор приділяе розкриттю питання створення та реформування спеціалізованих антикорупційних судів Тіпікор. В Індонезї̈ антикорупційний суд було створено у 2002 році, із прийняттям відповідного закону. Він знаходився в Джакарті - столиці країни. Після реформи 2009 року у всіх 34 індонезійських провінціях були створені антикорупційні тіпікор суди. У статmі з'ясовані наслідки такої реформи та надана оцінка ї̈ доцільності.

Проаналізовано, що головною проблемою такої реорганізаціі став дефіuит кадрів, котрі відповідають кваліфікаційним вимогам, прописаним у законодавстві. Зроблено висновок, що відповідні супутні виклики е тимчасовими й можуть бути усунені, а переваги такого реформування $е$ віочут- ними. Вони полягають у збільшенні рівня доступності антикорупційного правосуддя у регіонах, зменшенні часових та матеріальних витрат на доставлення матеріалів справи та свідків до суду. Відсутність пониження оцінки 32009 по 2019 рік Індонезії в міжнародному індексі сприйняття світової корупиіï свідчить про повільний, але успішний рух країни у протидї цьому негативному явищу.

Також було встановлено, шо з утворенням регіональних антикорупційних судів підвищується рівень спеціалізації суддів у їх професійній сфері - розгляді злочинів, пов'язаних зі корупиією. Внаслідок иього судовий процес стає більи якісним та ефективним. З'ясовано, щзо при проведенні таких реформ ключовим має бути збереження та поширення на регіональні суди позитивних здобутків та досвіду функціонування «пілотного» суду Тіпікор, який успішно себе зарекомендував у роки своєї роботи.

На основі аналізу робіт зарубіжних вчених було окреслено подальші иляхи вдосконалення роботи спеціалізованих антикорупичійних судових інституцій Індонезії. З’ясовано, що такою «зоною росту» $\epsilon$ подальша повна діджиталізація судового проиесу. Ураховуючі географічні особливості країни, ие покращення є особливо актуальним. Зроблено висновок, що провадження електронного суду значно вплине на оптимізацію произесу та дасть змогу заощадити державні кошти.

Ключові слова: антикорупційний суд Індонезіі, суди Тіпікор, антикорупційна реформа в Індонезіi, спеціалізовані суди, електронний суд.

Maletov D. Administrative and legal framework for the organization and reform of the Indonesian Anticorruption Court Tipikor

The article examines the process of historical formation of Indonesian 
anti-corruption legislation. The author pays special attention to the disclosure of the issue of creation and reform of specialized anti-corruption courts Tipikor. Indonesian anticorruption court was established in 2002, with the adoption of the relevant law. It was located in Jakarta - the capital of Indonesia. Following the 2009 reform, anti-corruption Tipikor courts were established in all 34 Indonesian provinces. The article clarifies the consequences of such a reform and provides an assessment of its feasibility.

It is analyzed that the main problem of such reorganization was the shortage of staff that meet the qualification requirements prescribed by law. It is concluded that the relevant concomitant challenges are temporary and can be addressed, and the benefits of such reform are tangible. They are to increase the availability of anti-corruption justice in the regions, reduce the time and material costs of bringing case materials and witnesses to court. The lack of a downgrade from 2009 to 2019 in Indonesia's international perception of global corruption indicates a slow but successful movement of the country in counteracting this negative phenomenon.

It was also found that with the establishment of regional anticorruption courts, the level of specialization of judges in their professional sphere - consideration of the category of crimes related to corruption is increasing. As a result, the trial becomes better and more efficient. It was found that in carrying out such reforms, the key should be to preserve and disseminate to the regional courts the positive achievements and experience of the "pilot" court Tipikor, which has successfully proven itself over the years.

Based on the analysis of the works of foreign scholars, further ways to improve the work of special anticorruption judicial institutions in Indonesia were outlined. It turned out that such a "growth zone" is the further complete digitalization of the trial. Given the geographical features of the country, this improvement is particularly relevant. It is concluded that the e-court proceedings will significantly affect the optimization of the process and will save public funds.

Key words: Indonesian anticorruption court, Tipikor courts, anti-corruption reform in Indonesia, specialized courts, electronic court.

\section{Лiтература}

1. Transparency International Corruption Perceptions Index: Indonesia. URL: https: / / www.transparency.org / en / cpi / $2020 /$ index/idn.

2. Najih, M., \& Wiryani, F. (2020). Learning the Social Impact of Corruption: A Study of Legal Policy and Corruption Prevention in Indonesia and Malaysia. Journal of Social Studies Education Research, 11(4), 175-189.

3. Schutte S. A. Specialised Anti-Corruption Courts: Indonesia. U4 Brief. 2016. URL: https: / / www.cmi.no/publications/ file/5886-specialised-anti-corruption-courts-indonesia.pdf.

4. Butt Simon. Indonesia's Regional Anti-Corruption Courts: Should They Be Abolished. Indon. L. Rev., 2012, 2: 145. URL: https: / / pdfs.semanticscholar.org / 8833 / $08056 b 00637$ eac2570cf8c7aea161fb8c8fd. $p d f$.

5. SHS Web of Conferences 54, 08010 (2018) The Tipikor Trial Model Based on IT In implementation of The Hearing on The Islands To Be Fast, Lightweight Cost and Simple Sulistyanta*, Sebastianus Adi Santoso Mola, Fredyk M Haba Djingi and Fatma Ayu Jati Putri Faculty of Law, Nusa Cendana University, Kupang, Indonesia. URL: https: / / www.shs-conferences.org / articles / shsconf / pdf/2018/15/shsconf_ icolgas2018_08010.pdf.

6. Novera, A., \& Pratama, K. J. (2020). Construct the Implementation of Electronic Justice System in the Indonesian Court for Corruption Crimes. Available at SSRN 3542723. URL: https://papers.ssrn.com/ sol3 $/$ papers.cfm?abstract_id $=3542723$. 